\title{
Mozambique's charcoals: anatomy of nine native species
}

\author{
Carbones de Mozambique: anatomía de nueve especies nativas
}

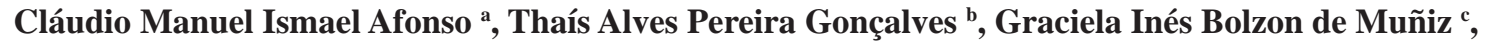 \\ Jorge Luis Monteiro de Matos ${ }^{\text {, }}$, Silvana Nisgoski ${ }^{\text {c* }}$ \\ ${ }^{a}$ Ministry of Agriculture, National Directorate of Land and Forestry, Av. Josina Machel, 537, Maputo, Mozambique, Africa. \\ ${ }^{b}$ Federal University of Parana, Doctoral Student of Forest Engineering. Av. Pref. Lothário Meissner, 632, Jardim Botânico, \\ 80.210-170, Curitiba, PR, Brazil. \\ *Corresponding author: ${ }^{\mathrm{c}}$ Federal University of Parana, Department of Forest Engineering and Technology, Av. Pref. Lothário \\ Meissner, 632, Jardim Botânico, 80.210-170, phone: (55) 41 - 3360-4275, Curitiba, PR, Brazil, silvana.ufpr@gmail.com
}

\section{SUMMARY}

\begin{abstract}
Most of the charcoal commercially produced in Mozambique is from natural forests, including high value species. This production often negatively affects the environment and one of the main reasons is the lack of sustainable forest management techniques. To facilitate forest control, we characterize the anatomy properties of charcoal made from Afzelia quanzensis, Amblygonocarpus andongensis, Combretum imberbe, Dalbergia melanoxylon, Guibourtia conjugata, Khaya nyasica, Millettia stuhlmannii, Pterocarpus angolensis and Swartzia madagascariensis. All these species possess high commercial value. The samples were carbonized at $450{ }^{\circ} \mathrm{C}$ for $1 \mathrm{~h}$. Some shrinkage-related ruptures were present in charcoals, but the structure kept good definition of the cells features and did not influence the distinction of the species. The propagation of this knowledge would relieve pressure on valuable species and may also help with control of the charcoal supply chain.
\end{abstract}

Key words: carbonization, anatomical characteristics, commercial wood, wood anatomy.

\section{RESUMEN}

La mayor parte del carbón producido en el comercio en Mozambique es de bosques naturales, incluyendo las especies de alto valor comercial. Esta producción afecta negativamente el medio ambiente y una de las principales razones es la falta de técnicas de manejo forestal sostenible. Para facilitar el control del uso de los bosques, se caracterizan las propiedades de anatomía de carbón vegetal a base de Afzelia quanzensis, Amblygonocarpus andongensis, Combretum imberbe, Dalbergia melanoxylon, Guibourtia conjugata, Khaya nyasica, Millettia stuhlmannii, Pterocarpus angolensis y Swartzia madagascariensis. Todas estas especies tienen un alto valor comercial. Las muestras fueron carbonizadas a $450{ }^{\circ} \mathrm{C}$ durante $1 \mathrm{~h}$. Algunas rupturas relacionadas con las pérdidas estuvieron presentes en los carbones, pero la estructura mantuvo buena definición de las características anatómicas de las células y no influyeron en la distinción de las especies. La difusión de este conocimiento podría aliviar la presión sobre las especies valiosas y también puede ayudar con el control de la cadena de suministro de carbón.

Palabras clave: carbonización, características anatómicas, maderas comerciales, anatomía de la madera.

\section{INTRODUCTION}

Mozambique has a great diversity of natural forests, and forestry biomass has an important role due to its en vironmental, social and economic dimensions (Vasco and Costa 2009). Biomass ener gy in the form of charcoal or firewood is used by over $85 \%$ of urban households in Mozambique. Charcoal commerce covers an extensive value chain, from those at the production sites to those transporting and retailing it in the cities. Despite the dimension of this sector, it is a largely informal activity with limited recorded information (Vasco and Costa 2009, Cuvilas et al. 2010). Practically all the charcoal comes from natural forests. The production is characterized by a lack of sus tainable forest management techniques; thus threatening natural resources (Bila 2005).

The estimated allowable cutting of trees in Mozambique is about two million cubic meters per year (Marzoli 2007). Regarding its commercial and scientific value, rarity, utility, resistance and quality, species which produce wood are classified into precious, first class, second class, third class and fourth class (Ministério da Agricultura). Some authors commented by Ali et al. (2008) explain that there are 118 wood species listed in the National Forestry Rules Guidelines classified in accordance with their value and some, classified as precious and first class, such 
as Berchemia zeyheri (Sond.) Grubov (pau-rosa), Spirostachys africana Sond. (sandalo), Swartzia madagascariensis Desv. (pau-ferro), Afzelia quanzensis Welw. (chanfuta), Milletia stuhlmannii Taub. (jambirre), Pterocarpus angolensis DC. (umbila), Androstachys johnsonii Prain. (mecrusse) and Combretum imberbe Wawra (monzo) are in declining availability in the Mozambican forests.

For energy purposes it is not allowed the use of wood from precious, first, second and third class, as well as those species that are scarce, protected or with historic and cultural value (Ministério da Agricultura 2002). Nevertheless, in Mozambique this is widely disobeyed by charcoal producers, because the choice of species for production depends on its availability and local culture (Bila 2005). In 2010 the use of firewood to produce charcoal was more than eleven million cubic meters (Steierer 2011). In African countries, the use of firewood and charcoal has been increasing as a consequence of urbanization and economic growth. This situation concerns environmentalists and those responsible for the management of forestry resources (Girard 2002, Clancy 2008).

Several studies have demonstrated that the anatomical structure of wood is maintained after carbonization (Kim and Hanna 2006, Gonçalves et al. 2012, Muñiz et al. 2013, Nisgoski et al. 2014). These authors have shown it is possible to identify species by examining charcoal samples. There are no scientific papers focusing on the features of charcoal made from species native to Mozambique. Along with this, literature on the anatomical features of arboreal species is not widely known in Mozambique, which contributes to the weak forestry control.

The present study characterizes the charcoal anatomy of nine species from Mozambique. All the species are prohibited for energetic purposes. We aim at contributing to the knowledge of these species and at helping to improve the forestry control.

\section{METHODS}

The samples were obtained from trees without a defined age growing in natural forests in Cabo Delgado (E39 $\left.{ }^{\circ} 17^{\prime} 01.70^{\prime \prime} \mathrm{S} 12^{\circ} 09^{\prime} 17.82\right)$ and Sofala (E34 $\left.50^{\circ} 34.79^{\prime \prime}, \mathrm{S} 17^{\circ} 30^{\prime} 21.19^{\prime \prime}\right)$, provinces of Mozam bique with annual average precipitation varying from 800 to $1,200 \mathrm{~mm}$ and predominant tropical and humid climate (INDE 2009). All the species chosen are native and pos sess high commercial value (table 1). For each species, three trees were randomly chosen for felling. The samples were taken as discs at breast height. The thickness of the discs was $5 \mathrm{~cm}$ with diameterof $18-35 \mathrm{~cm}$ outside the bark. All samples were free from defects. For the analyses, the samples were cut into blocks measuring $2.5 \times 2.5 \times 5 \mathrm{~cm}$.

The samples were wrapped in aluminum foil and carbonized in an electric muffle furnace at $450{ }^{\circ} \mathrm{C}$ for 1 hour, with a heating rate of $7.5^{\circ} \mathrm{C}$ per minute. After carbonization, the samples were cooled and weighed.

For anatomical analyses, the charcoal was broken by hand following the three structural planes of the wood and analyzed under a Zeiss Discovery v12 stereo microscope. The anatomical description was done based on the procedures of the Iawa Committee (1989). The images of charcoal were obtained by scanning electron microscopy with a ta bletop microscope (Hitachi TM-1000). No metallic-sputtercoating was needed. The determination of qualitative anatomical features was based on 25 measurements of tangential vessel diameter $(\mu \mathrm{m})$, vessel frequency (vessels $\mathrm{mm}^{-2}$ ), ray frequency $\left(\right.$ rays $\left.\mathrm{mm}^{-1}\right)$, ray width $(\mu \mathrm{m})$ and ray height $(\mu \mathrm{m})$.

\section{RESULTS}

The anatomical characteristics of the charcoal samples are summarized in quantitative (table 2) and qualitative (table 3) features, and illustrated in figures 1 - 3.

Table 1. List of species studied.

Lista de las especies estudiadas.

\begin{tabular}{lllc}
\hline \multicolumn{1}{c}{ Scientific name } & Commercial name & \multicolumn{1}{c}{ Family } & Commercial class \\
\hline $\begin{array}{l}\text { Afzelia quanzensis Welw. } \\
\text { Combretum imberbe Wawra }\end{array}$ & Chanfuta & Caesalpiniaceae & First \\
Khaya nyasica Stapf ex Baker F. & Mondzo & Combretaceae & First \\
Millettia stuhlmannii Taub. & Umbaua & Meliaceae & First \\
Pterocarpus angolensis DC. & Jambire & Fabaceae & First \\
Swartzia madagascariensis Desv. & Umbila & Fabaceae & First \\
Dalbergia melanoxylon Guill. et Perr. & Pau-ferro & Caesalpiniaceae & First \\
Guibourtia conjugata (Bolle) J. Léonard & Pau-preto & Fabaceae & Precious \\
Amblygonocarpus andongensis (Welw. Ex Oliv.) Exell et Torre & Mutiria & Caesalpiniaceae & Precious \\
\hline
\end{tabular}

Source: Ministério da Agricultura (2002). 
Table 2. Mean values and standard deviations of quantitative anatomical features of charcoal from nine Mozambique species.

Valores medios y error estándar de las características anatómicas cuantitativas del carbón de nueve Mozambique especies.

\begin{tabular}{lrccrc}
\hline \multicolumn{1}{c}{ Species } & $\begin{array}{c}\text { Vessel } \\
\mathrm{mm}^{-2}\end{array}$ & $\begin{array}{c}\text { Vessel diameter } \\
(\mu \mathrm{m})\end{array}$ & $\begin{array}{c}\text { Ray } \\
\mathrm{mm}^{-1}\end{array}$ & $\begin{array}{c}\text { Ray width } \\
(\mu \mathrm{m})\end{array}$ & $\begin{array}{c}\text { Ray height } \\
(\mu \mathrm{m})\end{array}$ \\
\hline Afzelia quanzensis & $6(1.8)$ & $166(25)$ & $6(1.7)$ & $48(8)$ & $223(39)$ \\
Amblygonocarpus andongensis & $23(3.4)$ & $116(32)$ & $6(1.1)$ & $39(5)$ & $221(45)$ \\
Combretum imberbe & $5(1.4)$ & $142(31)$ & $9(2.2)$ & $30(5)$ & $161(38)$ \\
Dalbergia melanoxylon & $11(1.9)$ & $114(33)$ & $9(1.8)$ & $29(8)$ & $156(47)$ \\
Guibourtia conjugata & $30(4.8)$ & $80(18)$ & $7(1.5)$ & $38(7)$ & $303(76)$ \\
Khaya nyasica & $20(3.0)$ & $127(40)$ & $4(2.4)$ & $83(21)$ & $426(106)$ \\
Millettia stuhlmannii & $11(1.7)$ & $202(72)$ & $6(2.4)$ & $42(10)$ & $199(25)$ \\
Pterocarpus angolensis & $9(1.1)$ & $182(39)$ & $10(3.2)$ & $38(7)$ & $106(16)$ \\
Swartzia madagascariensis & $20(3.9)$ & $70(20)$ & $9(2.0)$ & $28(5)$ & $124(15)$ \\
\hline
\end{tabular}

Table 3. Summary of qualitative anatomical features of charcoal from nine species.

Resumen de las características anatómicas cualitativas del carbón de nueve especies.

\begin{tabular}{|c|c|c|c|c|c|c|c|c|c|}
\hline Species & GR & OD & PP & IP & Axial parenchyma & RW & $\mathrm{RCC}$ & $\mathrm{SS}$ & MI \\
\hline Afzelia quanzensis & $\sqrt{ }$ & $\sqrt{ }$ & Simple & Alternate & $\begin{array}{l}\text { Lozenge-aliform, confluent, } \\
\text { and marginal }\end{array}$ & $2-3$ & A & Absent & $\sqrt{ }$ \\
\hline $\begin{array}{l}\text { Amblygonocarpus } \\
\text { andogensis }\end{array}$ & $\sqrt{ }$ & $\sqrt{ }$ & Simple & Alternate & Aliform, confluent and marginal & $1-2$ & A & Absent & $\sqrt{ }$ \\
\hline $\begin{array}{l}\text { Combretum } \\
\text { imberbe }\end{array}$ & $\sqrt{ }$ & $\sqrt{ }$ & Simple & Alternate & $\begin{array}{l}\text { Vasicentric, aliform, confluent } \\
\text { and in bands }\end{array}$ & $1-2$ & $\mathrm{D}$ & Absent & $\sqrt{ }$ \\
\hline $\begin{array}{l}\text { Dalbergia } \\
\text { melanoxylon }\end{array}$ & $\sqrt{ }$ & $\sqrt{ }$ & Simple & Alternate & $\begin{array}{l}\text { Vasicentric and diffuse-in-aggregates, } \\
\text { aliform, confluent, marginal }\end{array}$ & $1-2$ & A & $\begin{array}{l}\text { Rays, axial } \\
\text { parenchyma, vessels }\end{array}$ & $\sqrt{ }$ \\
\hline $\begin{array}{l}\text { Guibourtia } \\
\text { conjugata }\end{array}$ & $\sqrt{ }$ & $\sqrt{ }$ & Simple & Alternate & $\begin{array}{l}\text { Vasicentric, aliform, confluent, } \\
\text { marginal }\end{array}$ & 3 & A & Absent & $\sqrt{ }$ \\
\hline Khaya nyasica & $\sqrt{ }$ & $\sqrt{ }$ & Simple & Alternate & Vasicentric and scanty & $2-5$ & $\mathrm{C}$ & Absent & $\sqrt{ }$ \\
\hline $\begin{array}{l}\text { Millettia } \\
\text { stuhlmannii }\end{array}$ & - & $\sqrt{ }$ & Simple & Alternate & Confluent and bands & $1-3$ & A & $\begin{array}{l}\text { Rays, axial } \\
\text { parenchyma, vessels }\end{array}$ & $\sqrt{ }$ \\
\hline $\begin{array}{l}\text { Pterocarpus } \\
\text { angolensis }\end{array}$ & $\sqrt{ }$ & $\sqrt{ }$ & Simple & Alternate & Aliform,confluent and bands & $1-2$ & A & $\begin{array}{l}\text { Rays, axial } \\
\text { parenchyma, vessels }\end{array}$ & $\sqrt{ }$ \\
\hline $\begin{array}{l}\text { Swartzia } \\
\text { madagascariensis }\end{array}$ & $\sqrt{ }$ & $\sqrt{ }$ & Simple & Alternate & Aliform, confluent and bands & $1-2$ & A & $\begin{array}{l}\text { Rays, axial } \\
\text { parenchyma, vessels }\end{array}$ & $\sqrt{ }$ \\
\hline
\end{tabular}

Legend: GR - growth ring; OD - other deposits; PP - perforation plates; IP- intervessel pits; RW - ray width; RCC - rays: cellularcomposition; Rays: cellular composition: A - all ray cells procumbent; B - body ray cells procumbent with one row of upright and/or square marginal cells; C - body ray cells procumbent with mostly 2 to 4 rows of upright and/or square maginal cells; D - rays with procumbent, square and upright cells mixed throughout the ray; $\mathrm{SS}$ - storied structure; $\mathrm{MI}$ - mineral inclusions.

Shrinkage-related ruptures (figure 4) were observed in samples of Afzelia quanzensis, Amblygonocarpus andongensis, Dalbergia melanoxylon, Guibourtia conjugata, Khaya nyasica, Pterocarpus angolensis and Swartzia madagascariensis. Dalbergia melanoxylon presented ruptures in a parallel direction and perpendicular to the rays and P. angolensis only ruptures perpendicular to the rays. The other species only presented ruptures oriented in the direction of the rays.

\section{DISCUSSION}

The qualitative anatomical structures of charcoal are the same as those observed in the description of the wood from these species analyzed in other studies. The database of Inside Wood (2012) contains the anatomical description of the hardwood species Afzelia quanzensis, Amblygonocarpus andongensis, Combretum imberbe, Dalbergia me- 


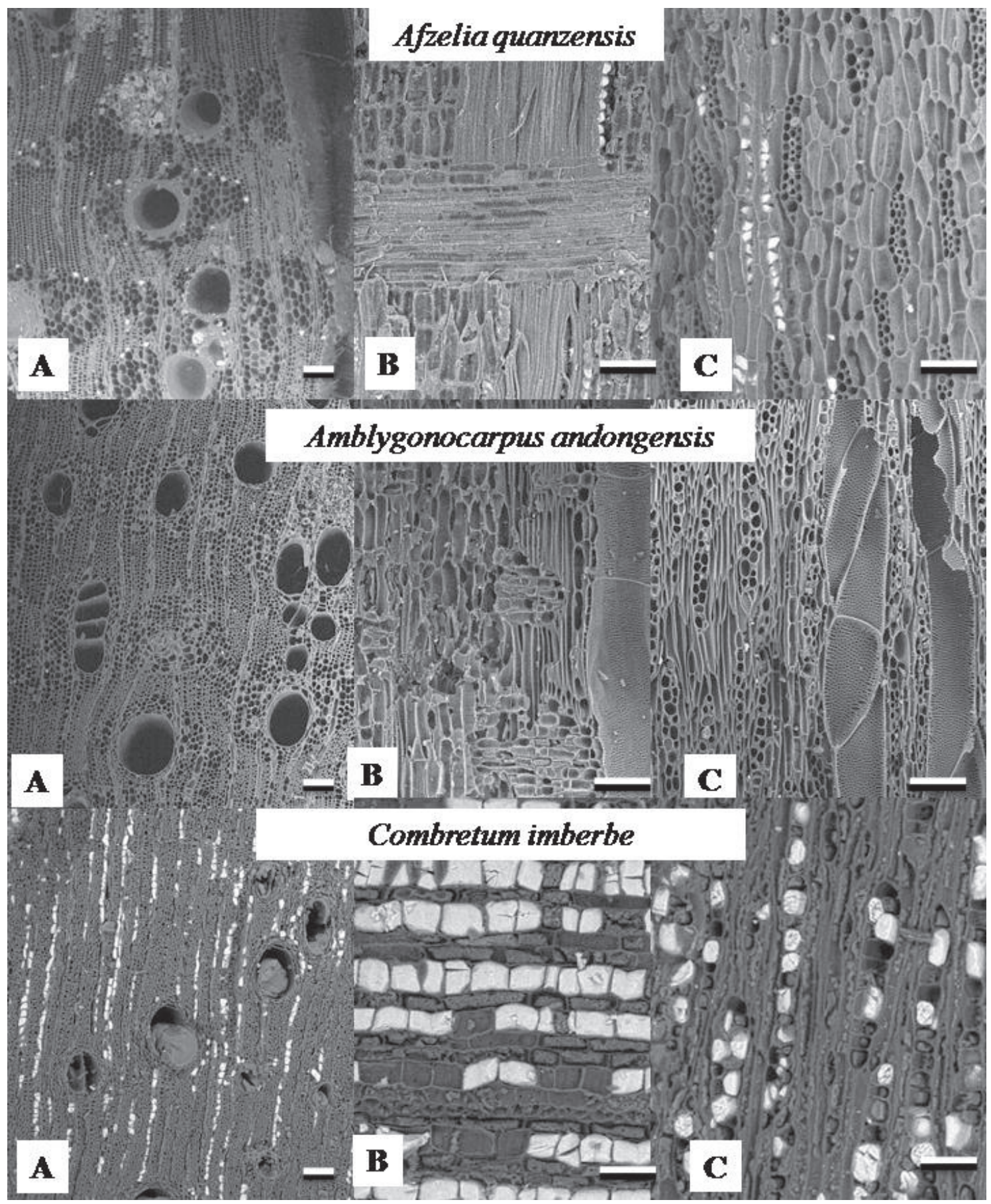

Figure 1. Scanning electron microscopy: images of transversal (A), radial (B) and tangential (C) section of charcoal. Scale bar $=100 \mu \mathrm{m}$. Microscopía electrónica de barrido: imágenes de la sección transversal (A), radial (B) y tangencial (C) del carbón. Escala $=100 \mu \mathrm{m}$.

lanoxylon, Millettia stuhlmannii, Pterocarpus angolensis, Swartzia madagascariensis; Richter and Dallwitz (2000) described the hardwood of A. quanzensis, D. melanoxylon, Guibourtia conjugata, Khaya nyasica, M. stuhlmannii, P. angolensis, S. madagascariensis; and Ali et al. (2008) reviewed the anatomical characteristics of the hardwood of A. quanzensis, K. nyasica, P. angolensis, M. stuhlmannii.
The carbonization at $450{ }^{\circ} \mathrm{C}$ and $7.5^{\circ} \mathrm{C}$ per minute of heating rate preserved well the structure of charcoal with good definitions of the cells features. Other works reported similar behaviors at different temperatures and/or heating rate, e.g: (i) Dichrostachys cinerea (L.) Wight et Arn. (Leguminosae) and Salix subserrata Willd. (Salicaceae) carbonized at $400{ }^{\circ} \mathrm{C}$ and $6.67{ }^{\circ} \mathrm{C}$ per minute (Prior and 


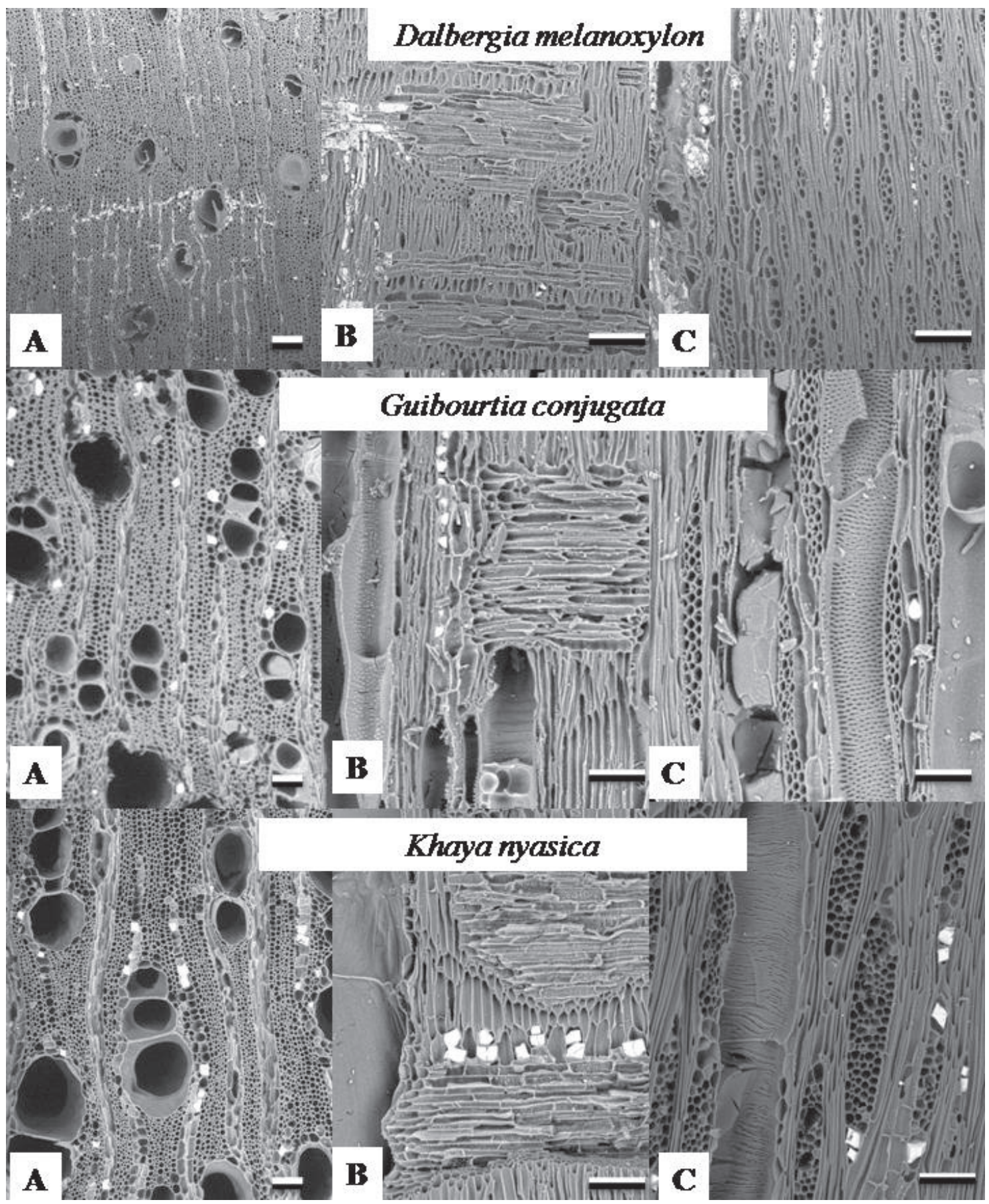

Figure 2.Scanning electron microscopy: images of transversal (A), radial (B) and tangential (C) section of charcoal. Scale bar $=100 \mu \mathrm{m}$. Microscopía electrónica de barrido: imágenes de la sección transversal (A), radial (B) y tangencial (C) del carbón. Escala = $100 \mu \mathrm{m}$.

Alvin 1983); (ii) Quercus variabilis Bl. at $450^{\circ} \mathrm{C}$ and $5{ }^{\circ} \mathrm{C}$ per minute (Kwon et al. (2009) (iii) Corymbia spp. and Eucalyptus spp. carbonized at $450{ }^{\circ} \mathrm{C}$ and $1.66{ }^{\circ} \mathrm{C}$ per minute (Gonçalves et al. 2014), (iv) Ocotea porosa (Ness et Mart.) Barroso carbonized at temperatures varying from $350-650{ }^{\circ} \mathrm{C}$ and heating rate from $1.04-1.24{ }^{\circ} \mathrm{C}$ per minute (Nisgoski et al. 2014). Kim and Hanna (2006), studying
Quercus variabilis BL. observed destroyed fiber walls, explaining that this effect is due to the tensions created by the effect of temperatures over $400{ }^{\circ} \mathrm{C}$. Prior and Alvin (1983) evaluated the anatomical changes as being due to the increase of temperature in the woods of Dichrostachys cinerea and Salix subserrata. They found that over $300^{\circ} \mathrm{C}$, the cell walls begin to acquire amorphous features in the 


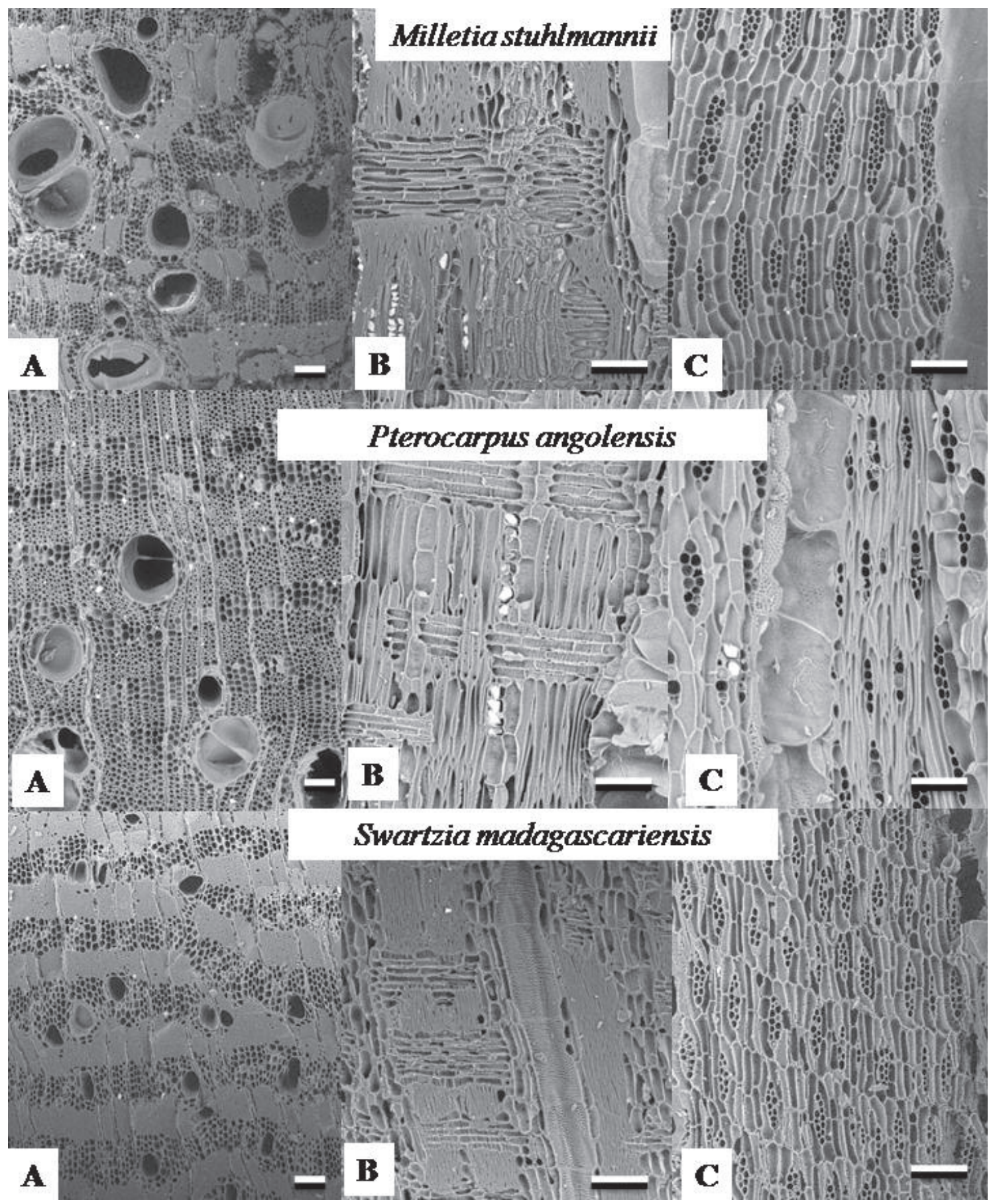

Figure 3.Scanning electron microscopy: images of transversal (A), radial (B) and tangential (C) section of charcoal. Scale bar $=100 \mu \mathrm{m}$.

Microscopía electrónica de barrido: imágenes de la sección transversal (A), radial (B) y tangencial (C) del carbón. Escala = $100 \mu \mathrm{m}$.

charcoal, although the medium line of the lamella and primary wall could still be distinguished. Kwon et al. (2009) studied Q. variabilis and found that over $350{ }^{\circ} \mathrm{C}$ it was impossible to observe the fiber walls.

Ruptures are also observed in other works in: (i) rays Corymbia citriodora (Hook.) K.D.Hill et L.A.S. Johnson, C. maculata (Hook.) K.D.Hill et L.A.S. Johnson, Eucalyp- tus dunnii Maiden, E. tereticornis Sm. and E. viminalis Labill. (Gonçalves et al. 2014), Quercus variabilis, Q. robur L. (Kim and Hanna 2006) and Q. alba L. (McGinnes et al. 1971); (ii) axial parenchyma cells - E. dunnii (Gonçalves et al. 2014); (iii) fibers - Mimosa tenuiflora (Willd.) Poiret and M. ophthalmocentra Martius (Dias Leme et al. 2010). As the causes of ruptures are not yet explained, our results 


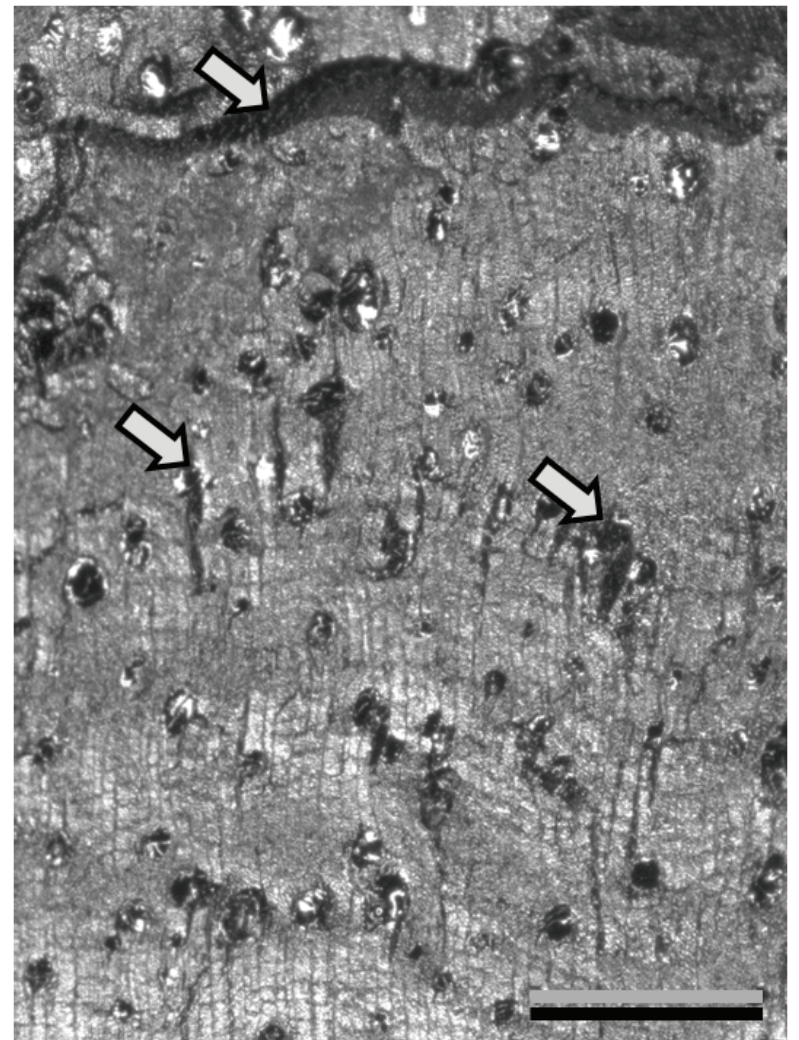

Figure 4. Ruptures in Dalbergia melanoxylon charcoal. Scale bar $=100 \mu \mathrm{m}$.

Rupturas en Dalbergia melanoxylon carbon. Escala $=100 \mu \mathrm{m}$.

were expected and did not compromise the identification of the anatomical features. Moreover, ruptures apparently did not influence charcoal quality.

The charcoal of species studied presented prismatic crystals in the cells of axial parenchyma of Afzelia quanzensis, Amblygonocarpus andongensis, Dalbergia melanoxylon, Guibourtia conjugata, Millettia stuhlmannii, Pterocarpus angolensis and Swartzia madagascariensis. In the case of Combretum imberbe and Khaya nyasica, these were only observed in the ray cells.

\section{CONCLUSIONS}

Anatomical changes due to carbonization do not influence the distinction of species. The knowledge of charcoal anatomy can help in the control of the species in the charcoal supply chain. We hope this kind of study can be multiplied in order to contribute with nature conservancy in Mozambique.

\section{ACKNOWLEDGEMENTS}

We thank the Ford Foundation and Federal University of Paraná (UFPR), Brazil, for support and the opportunity provided to conduct this research.

\section{REFERENCES}

Ali AC, E Uetimane Jr, IA Lhate, N Terziev. 2008. Anatomical characteristics, properties and use of traditionally used and lesser-known wood species from Mozambique: a literature review. Wood Science and Technology 42(6): 453-472. DOI:10.1007/s00226-008-0186-5

Bila A. 2005. Estratégia para a fiscalização participativa de florestas e fauna bravia em Moçambique.TCP/MOZ/2904 (A) Support for the implementation of forest and wildlife legislation in Mozambique. Maputu, Mozambique. DNFFB/ FAO. $42 \mathrm{p}$.

Clancy JS. 2008. Urban ecological footprints in Africa. African Journal of Ecology 46(4): 463-470. DOI: 10.1111/j.13652028.2008.01041.x

Cuvilas CA, R Jirjis, C Lucas. 2010. Energy situation in Mozambique: A review. Renewable and Sustainable Energy Reviews 14(7): 2139-2146. DOI:10.1016/j.rser.2010.02.002

Dias Leme CL, C Cartwright, P Gasson. 2010. Anatomical changes to the wood of Mimosa ophthalmocentra and Mimosa tenuiflora when charred at dif ferent temperatures. IAWA Journal 31(3): 333-351. DOI: 10.1163/22941932-90000027

Girard P. 2002. Charcoal production and use in Africa: what future? Unasylva 53(211): 30-35.

Gonçalves TAP, CR Marcati, R Scheel-Ybert. 2012. The effect of carbonization on wood structure of Dalbergia violaceae, Stryphnodendron polyphyllum, Tapirira guianensis, Vochysia tucanorum, and Pouteria torta from the Brasilian cerrado. IAWA Journal 33(1): 73-90.

Gonçalves TAP, AW Ballarin, S Nisgoski, GIB Muñiz. 2014. A contribution to the identification of charcoal origin in Brazil i: anatomical characterization of Corymbia and Eucalyptus. Maderas Ciencia y Tecnologia 16(3): 323-336. DOI: $10.4067 / \mathrm{S} 0718-221 \mathrm{X} 2014005000025$

IAWA COMMITTEE. 1989. IAWA List of microscopic features for hardwood identification. IAWA Bulletin 10(3): 219-332.

INDE (Instituto Nacional do Desenvolvimento da Educação, MZ). 2009. Atlas de Moçambique. Maputo-Moçambique.

Inside Wood. 2012. Inside Wood - Search the Inside Wood Database. Acessed 10 october 2012. Disponible: http://insi dewood.lib.ncsu.edu/search. $0 ;$ jsessionid $=$ c83f708ab41790 e999eda14d529d.

Kim NH, RB Hanna. 2006. Morphological characteristics of Quercus variabilis charcoal prepared at different temperatures. Wood Science and Technology 40(5): 392-401. DOI:10.1007/s00226-005-0062-5

Kwon SM, N-H Kim, DS Cha. 2009. An investigation on the transition characteristics of the wood cell walls during carbonization. Wood Science and Technology 43(5-6): 487498. DOI:10.1007/s00226-009-0245-6

McGinnes Jr. EA, SA Kandeel, PS Szopa. 1971. Some structural changes observed in the transformation of wood into charcoal. Wood and Fiber 3(2): 77-83.

Marzoli A. 2007. Inventário florestal nacional. Maputo, Moçambique. Direcção Nacional de Terras e Florestas, Ministério da Agricultura.

Ministério da Agricultura. 2002. Regulamento da Lei de Florestas e Fauna Bravia. Decreto 12/2002. Maputo, Mozambique. p.1-45.

Muñiz GIB, ME Carneiro, S Nisgoski, MGL Ramirez, WLE Magalhães. 2013. SEM and NIR characterization of four forest 
species charcoal. Wood Science and Technology 47(4): 815823. DOI: 10.1007/s00226-013-0539-6.

Nisgoski S, GIB Muniz, FRR Bati sta, RE Mölleken. 2014. In fluence of carbonization temperature on the anatomical characteristics of Ocotea porosa (Nees et Mart. ex Nees) L. Barroso. Wood Science and Technology 48(2): 301-309. DOI: $10.1007 / \mathrm{s} 00226-013-0602-3$

Prior J, KLAlvin. 1983. Structural changes on charring woods of Dichrostachys and Salix from Southern Africa. IAWA Bulletin 4(4): 197-206.
Richter HG, MJ Dallwitz. 2000. Commercial timbers: Descrip tions, illustrations, identification, and information retrieval. Delta. Accessed 3 Oct. 2012. Available in: Disponible: http:// delta-intkey.com

Steierer BF. 2011. Highlights on wood fuel: 2004-2009. FAOSTAT-ForesSTAT. Rome, Italy. FAO. 4 p.

Vasco H, M Costa. 2009. Quantification and use of forest biomass residues in Maputo province, Mozambique. Biomass and Bioenergy 33: 1221-1228. DOI:10.1016/j.biom bioe.2009.05.008

Recibido: 11.06 .14

Aceptado: 20.01.15 